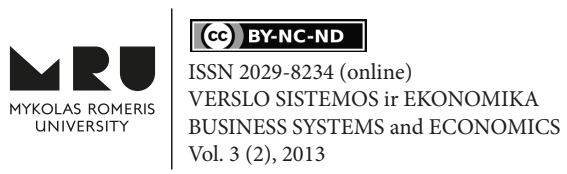

\title{
ALAUS GAMYBOS İMONIŲ SOCIALINĖS ATSAKOMYBĖS TYRIMAS
}

\author{
Margarita IŠORAITE் \\ Vilniaus kolegija \\ Didlaukio g. 49, LT-08303 Vilnius, Lietuva \\ Elektroninis paštas: misoraite@gmail.com \\ doi:10.13165/VSE-13-3-2-10
}

Santrauka: Straipsnyje analizuojama i̇monių socialinès atsakomybės sąvoka, Lietuvos ¿̇monių socialinès atsakomybès politika. Atliktas empirinis tyrimasparodé, kad visuomenę reikètų labiau supažindinti su įmonių socialinės atsakomybės sąvoka, labiau informuoti apie alaus gamybos įmonių veiklą visuomenès labui. Vykdančioms neatsakingą veiklą ịmonėms vis dèlto tikslinga būtų numatyti socialinę atsakomybę. Dauguma respondentų teigè, kad jie nèra girdèję apie socialinès atsakomybès programas, todèl būtina ateityje juos apie tai informuoti. Labai teigiamai respondentai vertino tokias priemones kaip aplinkos apsauga, dalyvavimas visuomeninèje veikloje, ịvairiapusis rẻmimas (sporto varžybų, kultūros renginių ir pan.). Pasak respondentų, visuomenè bei valdžios institucijos gali turèti pakankamai įtakos įmonių socialinei atsakomybei. Pagrindinès priežastys, skatinančios įmonès socialinę atsakomybę, yra geresnè ịmonès reputacija, gaunama „nemokama reklama“, klientų lojalumo didinimas bei finansinè nauda ịmonei.

Reikšminiai žodžiai: įmonès socialinė atsakomybè, socialinès atsakomybès politika, socialinè verslininko atsakomybè.

JEL klasifikacija: M10, M14.

\section{Ivadas}

İmonių socialinę atsakomybę (toliau - ir İSA) galima nagrinèti ịvairiais aspektais: pradedant socialiai atsakingos veiklos teikiama nauda visuomenei ir gamtai, baigiant atskirų grupių ịtaka İSA plètrai ir nauda pačioms įmonėms. Socialiai atsakingas verslas yra ganètinai nauja koncepcija, tačiau jo aktualumas ir plètra igauna pagreitị. Europos Sąunga jau kuris laikas aktyviai skatina ir plètoja atsakingo verslo modeli, vis daugiau politinio svorio suteikiant ISSA. Lietuvos Respublikos Vyriausybè taip pat deklaruoja savo indèli i I ISA teikdama įvairius teisinius aktus bei vykdydama socialiai atsakingą veiklą skatinančias programas. Tačiau reikètų pažymėti, kad Lietuvoje tik pradedamos diskusijos İSA klausimais orientuojantis ị klausimus „Ar reikia? ir „Kokia nauda iš to?", kai kitose šalyse pereita i aukštesnị lygmenị - kaip ir kokiomis priemonės igyvendinti İSA. Šiuo klausimu pastebimas dar vienas neigiamas kryptingumas - daugelis imonių ir visuomenès narių ISA vis dar supranta kaip reklaminę kampaniją, o ne kaip veiklos strategiją. Tokia tendencija ypač jaučiama kalbant apie alaus įmonių socialinę atsakomybę. 
Dabartiniu metu Lietuvoje, kaip ir visoje Europoje, stipreja imonių socialinès atsakomybės idèjų plètra. Mūsų šalyje taip pat tvirtėja verslo orientacija ị veiklą, kurios rezultatai yra nukreipti ne vien ị pelno siekimą, bet ir ị suinteresuotų veikejų poreikius bei tokias dimensijas, kaip žmogaus teisès, aplinkos tausojimas, socialinis solidarumas ir sanglauda. ISA idejos ir praktika pasiekia mūsų šalị ịvairiais keliais. Tam turi įtakos globalizacijos procesas, ES İSA politikabei konkrečios vietinès problemos, kurioms spręsti neužtenka iprastų metodų bei galiojančių ịstatymų.

Lyginant užsienio šalių ir Lietuvos patirtị İSA sferoje, galima pastebėti svarbius skirtumus. Pagrindinis veiksnys, skatinantis užsienio verslininkų atsakingą požiūrị, - vartotojų/ visuomenès spaudimas. Lietuvos įmonèse tokio pobūdžio iniciatyvos (projektai) dažniausiai yra skatinamos užsienio partnerių/antrinių įmonių. Šie projektai igyvendinami ịmonių viduje bei liečia tiesiogiai su jomis bendradarbiaujančius partnerius. Lietuvos įmonès, vykdydamos panašaus pobūdžio iniciatyvas, dažniausiai vadovaujasi vidiniais moraliniais/ etiniais poreikiais. Šis faktas rodo, jog Lietuvoje dar neveikia İSA koncepcijose aprašytas pagrindinis jo skatinimo mechanizmas - atsakas $\mathfrak{i}$ atsakingų vartotojų reikalavimus. Atsižvelgiant ị vieną iš plačiai paplitusių İSA sampratų, jog atsakingu gali būti laikomas verslas, kuris ne tik įvykdo visus šalyje numatytus reikalavimus verslui, laikosi ịstatymų ir pan., bet padaro daugiau, negu yra numatyta įstatymuose, galima teigti, kad daugumoje Lietuvos įmonių (nors ir esant tam tikrų pozityvių veiklų pavyzdžių) sunku kalbėti apie šio reiškinio vystymosi pradžią. Atrodo, jog kol kas Lietuvoje socialinė įmonių veikla daugiausiai yra suvokiama kaip labdara ar filantropija. Nemažai kompanijų skiria lěšu socialiniams projektams, tačiau tai vis tiek yra daugiau vienas iš marketingo būdų, o ne lygiavertės partnerystès bei sisteminio bendradarbiavimo užmezgimas su socialiniais partneriais bei kitais naudos gavejais (Darbo ir socialinių tyrimų institutas, Socialinès apsaugos ir darbo ministerija, Lietuvos Respublikos trišalè taryba (2006).

Kaip teigia Česynienè, Neverkevič (2009), ISA idejjos Lietuvoje kol kas menkai atsispindejo sisteminiuose moksliniuose tyrimuose, nors pastaruoju metu publikacijų skaičius šiais klausimais yra išaugęs. ISA problemas nagrinėjo Vasiljevienè, Gruževskis (2006), Vasiljevas, Pučètaitė (2005), Juščius ir Snieška (2008), Bernatonytè, Vilke ir Keizerienè (2009). İvairiais aspektais įmonių socialinės atsakomybės problemos minimos Čiegio (2003, 2009), Čiegio ir Gineitienès (2008), Grybaitès ir Tvaronavičienès (2008), Kriščiūno ir Grẻblikaitès (2007), Lapinskienès ir Tvaronavičienès (2009), Ruževičiaus ir Serafino (2006), Schieg (2009), Tafel-Viia ir Alas (2009)moksliniuose darbuose.

Straipsnio objektas - socialinė atsakomybė alaus gamybos įmonėse.

Straipsnio tikslas - ištirti ir ịvertinti kolegijos studentų požiūrị i alaus gamybos i̇monės socialinę atsakomybę ir pateikti pasiūlymus, kaip šią socialinę atsakomybę didinti visuomenèje.

Tikslui pasiekti nustatyti šie uždaviniai:

- Išanalizuoti socialinès atsakomybès sampratos teorinius aspektus;

- Išnagrinèti socialinę atsakomybę alaus gamybos sektoriuje;

- Ištirti respondentų nuomonę apie alaus sektoriaus įmonių socialinę atsakomybę ir jos poveiki visuomenei.

Taikyti tyrimo metodai: mokslinès literatūros analizè, teisinių dokumentų analizė, anketinè apklausa. 
Socialinès atsakomybès samprata, jos teoriniai aspektai nagrinejjami remiantis mokslinès literatūros analize. Teisinių dokumentų analizé pasitelkta ịvertinti įmonių socialinę politiką, kokiais teisès aktais ji apibrèžta bei kaip traktuojama. Anketinè apklausa žvalgomasis tyrimas, atliktas ištirti respondentų nuomonę apie alaus gamybos įmonių socialinę atsakomybę, kokị poveikị ji daro respondentams.

\section{Socialinės atsakomybės sampratos teoriniai aspektai}

Nagrinėjant įmonių socialinės atsakomybės apibrèžimus paaiškèjo, kad naudos sąvoka ISA apibrèžime atsirado viena pirmųjų. Dar $1776 \mathrm{~m}$. Smith’as vertindamas organizacijos veiklos kryptingumą akcentavo, jog imonè visų pirma turi siekti asmeninès ir materialinès naudos maksimizavimobei racionaliai naudoti turimus gamybos išteklius. Tuo metu ekonomikoje dar nebuvo aiškiai apibrèžta ir logiškai pagrịsta racionalumo sąvoka. Vis dèlto ja tuometinis mokslas jau disponavo aiškindamas organizacijos veiklos prioritetus. Šiuo atveju romantinės hermeneutikos taikymas leidžia tuometinę organizacinès elgsenos sampratą sugretinti su istorinėmis aplinkybèmis ir būtent tame kontekste apibrèžti įmonių socialinę atsakomybę. Taigi, tai leidžia teigti, jog pelno maksimizavimas tuo metu ir buvo tikroji įmonès paskirtis ir socialinė atsakomybė (Vaitkevičius irStukaitė, 2009).

Imonių socialinè atsakomybè - terminas, apimantis aplinkosauginių ir socialinių principų savanorišką ịtraukimą i i̇monių vidinius procesus ir santykius su visuomene. Šio reiškinio ir termino atsiradimui įtakos turèjo įvairūs veiksniai. Svarbiausi jų - tai vis spartejjanti globalizacija, nykstantys gamtos ištekliai, aplinkos tarša, daugelyje šalių vis dar išliekanti socialinė ir lyčių nelygybè, skurdas bei kitos reikšmingos problemos pasauliniu ir šalies mastu. Svarbu atkreipti dèmesi i vartojimą, kuris yra pagrịstas naftos ir kitų neatsinaujinančių išteklių naudojimu, kadangi visa žmonija ateityje rizikuoja ne tik savo ilgalaike gerove, bet ir mūsų planetos gyvavimo tęstinumu. Aplinkosaugos, socialinių ir ekonominių problemų sprendimo būtinumas tik įrodo, kad dabartinis ekonomikos modelis netenkina visuomenės lūkesčių ir kelia grèsmę būsimų kartų išlikimui.

Nacionalinejje i̇monių socialinès atsakomybès plètros 2009-2013 metų programoje apibrèžta, kad įmonių socialinè atsakomybè - tai įmonių politika ir praktika, kai jos, laikydamosi įstatymų, tarptautinių susitarimų ir sutartų elgsenos normų, ì savo veiklos vidinius procesus ir išorinius santykius savanoriškai integruoja socialinius, aplinkosaugos ir skaidraus verslo principus. Imonès kartu su visuomeniniais ir valstybinio sektoriaus partneriais ieško novatoriškų sisteminių socialinių, aplinkosaugos ir platesnių ekonominès gerovès problemų sprendimų.

Kaip teigia Šimanskienė ir Paužuolienè (2010), İSA matuojama ir institucionalizuojama remiantis keturiais pagrindiniais parametrais: a) rinkos; b) darbo vietos (vidine ISA); c) visuomenès ir d) aplinkosaugos (išorinė ISA). Remiantis šiais parametrais ir konkretizuojant bei pritaikant įmonių vadybą konkrečioms sąlygoms plètojamos ISA strategijos. Visa tai gali užtikrinti SA 8000 vadybos sistema. Standartas SA 8000 (Social ..., 2009) - tai reikalavimai, kurie gali būti taikomi beveik visų pramonès sričių įmonėms, kurios nori parodyti socialiai atsakingą požiūrị ị darbo sąlygų sudarymą ir palaikymą.

Kaip teigia Dagilienè ir Bruneskienė (2010), Lietuvoje įmonių socialinès atsakomybès sampratą tyrė Juscius (2009), Ruzevičius ir Serafinas (2007), įmonių socialinės atsakomybès iniciatyvų tendencijas - Astromskienè ir Adamonienė (2009). Jusčius ir Snieška (2008) 
pažymèjo, kad įmonès sugebejimas užtikrinti vartotojų poreikius, suderinus su kitomis suinteresuotojų grupemis, didina jos konkurencingumą. Ruzevičius ir Serafinas (2007), tirdami socialiaiatsakingo verslo plètrą Lietuvoje, nagrinèjo vienos organizacijos, įdiegusios ir sertifikavusios savo socialiaiatsakingo verslo vadybos sistemą. Dagilienè (2009) tyrè Lietuvos bendrovių, kotiruojamų vertybinių popieriųbiržoje, finansinių ataskaitų sudètingumą, naudojant privalomų finansinių ataskaitų, tarp jų ir metiniopranešimo, apimties kriterijų. Legenzova (2008), tirdama Lietuvos listinguojamų bendrovių savanoriškaiatskleidžiamos finansinès informacijos apimtị ir jos sąryšį su nuosavybès struktūra 2002-2005 m., nustatė, kad žemesnis savanoriškos informacijos atskleidimo lygis yra būdingas įmonèms, kurių aukšta kapitalokoncentracija. Vaškelienès, Selepeno atlikto tyrimo rezultatai parodè, kad 2006 m. įmonès daugiau atskleidè informacijos apie intelektinị kapitalą lyginant su 2003 metais. Taigi nors mokslinejje literatūroje yra pateiktaịvairių savanoriškai atskleidžiamos informacijostyrimų, vis dèlto trūksta İSA bei alaus sektoriaus ịmonių socialinès atsakomybèstyrimų.

Imonių socialinė atsakomybė nagrinėjama įmonès strateginių klausimų lygmeniu aplinkosaugos ir socialinius klausimus ịtraukiant ị verslo strategiją ir kasdieninę veiklą. Daugelyje literatūros šaltinių yra pateikiamos pagrindinès priežastys, kodèl İSA klausimai yra strateginės reikšmės (Socialinės apsaugos ir darbo ministerija (2012):

- Tai yra natūralus organizacijų vystymosi etapas atsižvelgiant $\mathfrak{i}$ besikeičiančius visuomenès lūkesčius;

- Senkantys natūralūs ištekliai tampa ribojančiu veiksniu vystant veiklą;

- Ekologinès problemos darosi globalaus masto;

- Dideja sveikatos problemos;

- Socialiniai, aplinkosaugos ir ekonominiai veiksniai tarpusavyje siejasi ir sukuria nestabilumą ir nesaugumą;

- Energijos tiekimo užtikrinimas yra pagrindinis klausimas;

- Darnaus vystymosi principų taikymo teigiamų pasekmiųgali būti daugiau, nei numatoma iš anksto.

ISSA pobūdis ir apimtis keitėsi bejgant laikui. İSA sąvoka yra santykinai nauja, plačiai vartojama tik nuo 1960 m. Tačiau ISA pamatai buvo padèti dar XVIII a., kai kuriems verslininkams reorganizuojant savo veiklą taip, kad būtų kiek įmanoma labiau pagerintos darbo sąlygos darbuotojams. Robertas Owenas (1771-1858) buvo vienas iš nedaugelio tuometinių verslininkų, kurie rūpinosi savo darbuotojų gerove ir tam tikrą pelno dalị skyre darbo sąlygų ir darbuotojų gyvenimo lygio kèlimui. R. Oweno parašytos knygos, kuriose jis išdèstèsavo idejas, bei sukurtos darbo sąlygos tekstilès fabrike davė pradžią socialinès atsakomybès koncepcijai. Pagrindinis R. Oweno įnašas ị socialiai atsakingą mąstymą buvo nuomonè, kad žmogaus socialinis elgesys nèra fiksuotas ar besąlyginis, kad kiekvienas žmogus turi laisvą valią burtis ị bet kokią visuomeninę bendruomenę (Carrasco, 2008).

Verslo socialinès atsakomybès koncepcija toliau buvo plètojama ir XIX a. Tačiau didžiųjų korporacijų savininkai demonstruodami akivaizdžią ịmonès socialinę atsakomybę iš tikrųjų buvo vedami savanaudiškų tikslų - tokia būdu buvo siekiama pakelti i̇monès socialinị prestižą bei maksimizuoti pelną (Pruskus, 2003).

Praeito amžiaus 7-ajame dešimtmetyje verslo etika, socialinė verslo atsakomybè bei korporacijų socialinè atsakomybè tapo vis dažniau diskutuojamomis temomis. Tam ypač didelę įtaką padarè ekonomisto G. Boyweno 1953 m. išleista knyga „Socialinè verslininko 
atsakomybe்“. Knygoje autorius socialinės atsakomybės koncepciją pateikẻ kaip verslininkų isipareigojimą vykdyti tokią veiklą ir politiką įmoneje bei priimti tokius sprendimus, kurie sutaptų su visuomenès vertybèmis bei tikslais (Prunskus, 2003). Prie socialiai atsakingo verslo plètros prisidejo ne tik žymūs teoretikai bei išleisti veikalai, tačiau ir skirtingų šalių ekonominès tradicijos: pavyzdžiui, Japonijoje jau daugeli metų ypatingai daug dèmesio buvo skiriama subalansuotai plètrai, kuri nèra įmanoma be i̇monių socialinès atsakomybès. Panašių iniciatyvųdaugejo ir kitose didžiosiose pasaulio šalyse, tokiose kaip JAV, Vokietija bei Skandinavijos šalyse (Tyrimo ataskaita (2007).

2006 m. kovo 22 d. Europos Bendrijų Komisija patvirtino ISA sąvokos apibrèžimą: „Imonių socialinė atsakomybė (IૃSA) yra sąvoka, kurią pasitelkdami verslininkai savanoriškai ittraukia socialinius ir aplinkosaugos klausimus ị savo įmonių veiklą ir ị santykius su suinteresuotosiomis šalimis“ (Komisijos Komunikatas Europos Parlamentui (2006). ES dokumentuose taip pat pateikiami pavyzdžiai, aiškinantys İSA koncepciją: „spręsdama socialines reikmes, įmonė nusprendžia neapsiriboti būtinais teisiniai reikalavimais ir ịsipareigojimai, kurie numatyti kolektyvinèse sutartyse" (Komisijos Komunikatas Europos Parlamentui (2006). ISA sąvokos apibrèžimas numato galimybę tiek didelėms, tiek mažoms įmonèms su suinteresuotomis šalimis derinti ekonominius, socialinius ir aplinkosaugos tikslus. Apibendrinant ES tvarką dèl İSA, svarbu paminèti, kad ES šalys narès pritaria pateiktam ISA apibrèžimui, tačiau kiekvienoje šalyje, priklausomai nuo šalies kultūros ir ekonominio išsivystymo lygio, gali skirtis jos ypatybès.

Pagal Socialinès apsaugos ir darbo ministerijos $2005 \mathrm{~m}$. patvirtintą dokumentą "İmonių socialinę atsakomybę 2006-2008 metais skatinančios priemonès“ i̇monių socialinè atsakomybė apibrěžiama kaip „imonių ideologija, politika bei praktika, atspindinti tokią immonių elgseną, kai jos ị savo veiklą savanoriškai ịtraukia socialinius ir aplinkosaugos klausimus bei santykiuose su visais suinteresuotais visuomenès, verslo ir valdžios atstovais vadovaujasi pagarbos žmogui, visuomenei bei gamtai vertybiniais principais“ (Socialinès apsaugos ir darbo ministerija (2012). Taip pat aiškinama, kad įmonių veikla siejama ne tik su akcininkų ir savininkųekonominès naudos gavimu, bet ir su imonès daromu poveikiu darbuotojams, tiekejams, apskritai visai visuomenei bei aplinkai.

Daugelyje literatūros šaltinių skiriamos keturios pagrindinès İSA plètros dalys, kurios supaprastina ir apibendrina ISA sąvokoje užkoduotą informaciją (Socialinès apsaugos ir darbo ministerija (2012):

- Konkurencingos įmonès besikeičiančiomis globalios ekonomikos sąlygomis;

- Saugi, ekologiškai švari aplinka;

- Stipri socialinè sanglauda;

- Skaidri ir etiška verslo praktika.

Imonès, siekdamos subalansuoti savo veiklą ir atitikti ISA reikalavimus, vadovaujasi tam tikromis taisyklemis ir standartais. Šiuolaikinis pasaulis racionaliai naudoja subalansuotas socialines humanistines vertybes ir ekonominę naudą derina su vadinamuoju „3E“ (angl. „3P“) principu (Marrewijk, 2003):

* Ekonomika/efektyvumas - Profit;

* Etika - People;

* Ekologija - Planet.

Ir literatūroje, ir visuomenèje pastebima tendencija antrąji principą „Etika - People“ išskirtinai tapatinti su socialine atsakomybe, tačiau tokia nuostataklaidinga. ISSA jungia visus tris principus, neišskirdama nè vieno jų. Kitaip tariant, socialinė atsakomybè sąmoningai 
kuria ekonominius, politinius, teisinius ir dorovinius santykius tarp organizacijų ir visuomenès. Visa tai apima socialiai atsakingo - darnaus verslo principus. Socialinè atsakomybe turi teisini pamatą šalies, tarptautinių bendrijų ir pasauliniu mastu. Didžiausia ir viena iš pagrindinių savanoriškų įmonių/korporacijų socialinės atsakomybès iniciatyvų yra Pasaulinis susitarimas (angl. „The Global Compact“), grindžiamas žmogaus teisių, darbuotojų teisių, aplinkosaugos ir kovos su korupcija principais, kurie taip pat yra ịtvirtinti:

- 1948 m. Visuotinejje žmogaus teisių deklaracijoje - tarptautiniame dokumente, skatinančiame valstybes ir jų piliečius laikytis žmogaus teisių ir laisvių, socialinių ir ekonominių, politinių ir pilietinių teisių;

- 1992 m. Rio de Žaneiro deklaracijoje dèl aplinkosaugos ir pletros - suformuluoti esminiai tvaraus vystymosi principai ir jų igyvendinimo programa. Aukščiausiu lygiu itteisinta tvarios plètros ideologija;

- 1998 m. Tarptautinès darbo organizacijos deklaracijoje dèl pagrindinių principų ir teisių darbe - suformuluoti tarptautiniai darbo standartai, nustatantys minimalius bazinius reikalavimus, darbo teisès atžvilgiu; $2000 \mathrm{~m}$. Jungtinių Tautų konvencijoje prieš korupciją - numatytas tinkamas, sąžiningas ir atsakingas valstybės ir jos turto tvarkymas, korupcijos stabdymas ir kova su ja.

- Taip pat verta paminèti 1997 m. pasirašytą Kioto protokolą (įsigaliojo 2005 m.) kovai su visuotiniu atšilimu, kaip vieną iš priemonių igyvendinant „3E“ principą.

Siekiant užtikrinti tarptautiniu mastu pripažįstamą socialinių darbo sąlygų lygị, tiek mažose, tiek didelèse i̇monèse diegiamas SA 8000 standartas. „SA 8000 standartas - tai išsamus, visuotinis, patikrinamas atitikties kolektyvinės atsakomybès reikalavimams auditavimo ir sertifikavimo standartas, kurio esmè - tikèjimas, kad visose darbo vietose turi būti remiamos pagrindinès žmogaus teisès, o vadovybè yra pasiruošusi prisiimti atsakomybę už tai“ (Pruskus, 2003). Standartas remiasi Tarptautinès darbo organizacijos konvencijomis, Visuotine žmogaus teisių deklaracija ir Jungtinių Tautų vaiko teisių konvencija. SA 8000 standarto sertifikatas apima devynias svarbiausias sritis, susijusias su: vaikų darbu; priverstiniu darbu; sauga ir sveikata; asociacijų laisve; bet kokia diskriminacija; disciplinarine praktika; darbo valandomis, darbo užmokesčiu ir efektyvia vadyba (Socialinès atsakomybès standartas (2008). Socialinès atsakomybės standartas vadybos sistemoje ittvirtina palankų ¡̇monès ịvaizdị visuomeneje, o tai, be abejo, turi įtakos įmonès ekonominès naudos augimui. Tačiau svarbiausia, kad šis standartas stiprina darbuotojų lojalumą ir motyvaciją, kas ypač gerina darbo kokybę bei nulemia pozityvius pokyčius organizacijoje ir efektyvesnị valdymą.

Nepaisant įvairių organizacijų veiklos siekiant ịprasminti atsakingo verslo praktiką, akademineje ir mokslineje literatūroje pateikiama nemažai argumentų „už“ ir „prieš socialiai atsakingą i̇monių elgseną. İSA teikiamą naudą galima išskaidyti ị dvi dalis: vidinè nauda (İSA nauda pačiai įmonei) ir išorinè nauda (IૃSA svarba visuomenei ir aplinkai). Remiantis Pasaulio banko atlikto tyrimo duomenimis, ISA teikiama nauda verslo i̇monèms apima pardavimų ir rinkos dalies didejjimą; prekinio ženklo sustiprèjimą, darbuotojų pritraukimo ir išlaikymo naudą; veiklos kaštų mažejjimą, teisinès rizikos ir draudimo išlaidų mažejimą; inovacinių produktų ir procesų bei geresnio gyvenimo kokybès kūrimą. Vienas geriausiai žinomų ISA kritikų buvo JAV ekonomistas M. Friedmanas. Jis teigè, kad socialiai atsakinga imonès veikla paneigia pelno didinimo principą. Jo manymu, vienintelè bendrovès socialiai atsakinga veikla yra demesio sutelkimas ị ekonominius interesus, paliekant socialinių problemų sprendimą valstybinems įstaigoms, labdaros ir visuomeninems organizacijoms (Mares, 2007). Kiti ne mažiau svarbūs pateikiami argumentai „prieš“ İSA yra papildomos 
išlaidos organizacijai, kurios galiausiai tenka pirkejjui, padidinant produkto ar paslaugos kainą; organizacija nèra tiesiogiai atsakinga visuomenei, kadangi valdytojų niekas nerenka, taip pat socialinių problemų sprendimo patirties stygius, nes bendrovès personalas pasirengęs veikti konkrečios ekonominès veiklos sferoje.

Juščius (2007) teigia, kad ịmonių socialinès atsakomybė teorijų palyginimas istoriniu ir sisteminiu teoriniu aspektais atskleidžia svarbius jų bruožus. İmonių socialinès atsakomybės (İSA) teorijų palyginimas pateikiamas 1 lentelèje.

1 lentelè. İmonių socialinès atsakomybės teorijų palyginimas

\begin{tabular}{|c|c|c|c|c|c|c|}
\hline $\begin{array}{c}\text { Teorijos } \\
\text { pavadinimas }\end{array}$ & $\begin{array}{c}\text { Požiūris i } \\
\text { İSA }\end{array}$ & $\begin{array}{c}\text { ISA } \\
\text { svarbus } \\
\text { laipsnis } \\
\end{array}$ & $\begin{array}{l}\text { Požiūris i } \\
\text { ISSA kaštus }\end{array}$ & ISA tikslai & $\begin{array}{c}\text { ISA } \\
\text { motyvai }\end{array}$ & $\begin{array}{c}\text { Pagrindiniai } \\
\text { argumentai }\end{array}$ \\
\hline $\begin{array}{c}\text { Agentavimo } \\
\text { teorija }\end{array}$ & $\begin{array}{c}\text { Kategoriš- } \\
\text { kai neigia- } \\
\text { mas }\end{array}$ & Nesvarbi & $\begin{array}{l}\text { Imonès } \\
\text { išteklių } \\
\text { švaistymas }\end{array}$ & $\begin{array}{c}\text { Už verslo } \\
\text { interesų ribų }\end{array}$ & $\begin{array}{l}\text { Ne ekono- } \\
\text { miniai }\end{array}$ & $\begin{array}{l}\text { Versle turi būti } \\
\text { paisoma tik akci- } \\
\text { ninkų interesų }\end{array}$ \\
\hline $\begin{array}{l}\text { Suinteresuo- } \\
\text { tụjų grupių } \\
\text { teorija }\end{array}$ & Teigiamas & Būtina & $\begin{array}{l}\text { Pateisinami } \\
\text { ilgu } \\
\text { laikotarpiu }\end{array}$ & \begin{tabular}{|} 
Pašalinti arba \\
sumažinti \\
suinteresuotujų \\
grupių \\
pasipriešinimą
\end{tabular} & $\begin{array}{l}\text { Veiklos } \\
\text { veiksmin- } \\
\text { gumo didi- } \\
\text { nimas }\end{array}$ & $\begin{array}{c}\text { Ilgu laikotarpiu } \\
\text { turi neigiamą } \\
\text { ittaką įmonių } \\
\text { finansiniams } \\
\text { rezultatams }\end{array}$ \\
\hline $\begin{array}{c}\text { Atsakingo } \\
\text { valdymo teo- } \\
\text { rija }\end{array}$ & Teigiamas & $\begin{array}{l}\text { Labai } \\
\text { svarbi }\end{array}$ & $\begin{array}{l}\text { Neišvengia- } \\
\text { mi }\end{array}$ & $\begin{array}{l}\text { Socialiniai- } \\
\text { etniniai }\end{array}$ & Moraliniai & $\begin{array}{c}\text { Vadovai privalo } \\
\text { elgtis moraliai } \\
\text { neatsi-žvelgdami } \\
\text { i finansinę nauda }\end{array}$ \\
\hline $\begin{array}{l}\text { Transakcijos } \\
\text { kaštų teorija }\end{array}$ & $\begin{array}{l}\text { Sąlygiškai } \\
\text { teigiamas }\end{array}$ & Abejotina & $\begin{array}{l}\text { Tik iš dalies } \\
\text { pateisinami }\end{array}$ & $\begin{array}{c}\text { Socialiniai, } \\
\text { tiesiogiai } \\
\text { nesusiję su } \\
\text { verslo tikslais }\end{array}$ & $\begin{array}{c}\text { Tik iš dalies } \\
\text { gali būti } \\
\text { ekonomi- } \\
\text { niai }\end{array}$ & $\begin{array}{c}\text { Griauna priva- } \\
\text { čios nuosavybès } \\
\text { teises, skatina } \\
\text { tikrosios verslo } \\
\text { atsakomybès } \\
\text { eroziją }\end{array}$ \\
\hline Išteklių teorija & $\begin{array}{c}\text { Labai } \\
\text { teigiamas }\end{array}$ & $\begin{array}{l}\text { Svarba } \\
\text { dideja }\end{array}$ & Būtini & $\begin{array}{c}\text { Ekonominių ir } \\
\text { socialinių tikslų } \\
\text { derinimas }\end{array}$ & Darni raida & $\begin{array}{c}\text { Koreliacija tarp } \\
\text { İSA kaštų ir } \\
\text { ilgalaikio įmonės } \\
\text { ekonominio } \\
\text { efektyvumo }\end{array}$ \\
\hline
\end{tabular}

Šaltinis: Juščius (2007)

Kaip teigia Dagilienė ir Bruneskienė (2010), nagrinėjant šiuos klausimus, pirmiausia reikètų aptarti, kokios įmonès sritys yra priskiriamos İSA. Svarbiausios İSA vertinimo sritys yra susijusios su aplinkosauga, žmogiškaisiais ištekliais, visuomene bei produkto kūrimu ir tobulinimu. İmonių socialinè atsakomybè dažnai yra siejama tik su jos aplinkosaugos politika bei aplinkosauginėsinformacijos atskleidimu. Vis dèlto tai yra per siauras aplinkos suvokimas įmonių socialinès atsakomybèstyrimo aspektu, nes veiksniai, susiję su aplinka, gali būti tiek aplinkosauginiai (ekologiniai), tiek socialiniai ekonominiai. Deegan and Gordon (1996) tyrè, kokia yra Australijos įmonių informacijos apie aplinkosaugą atskleidimo apimtis metinėse finansinèse ataskaitose, ir nustatė, kad įmonių aplinkosaugos atskleidimo didejjimas yra pozityviai susijęs su aplinkos apsaugos interesų grupių didejjimu. Taip pat buvo ištirta, kadteršiančios ịmonès atskleidžia santykinai daugiau informacijos apie 
aplinkos teršimą negu neteršiančiosįmonès. Atskleisdamos daugiau teigiamos informacijos apie aplinkosaugos veiklą, bendrovès tokiu būdusiekia sukurti teigiamą savo ịvaizdį visuomenèje.

Pasak Juščiaus (2007), nauji ịmonių socialinès atsakomybès teorijų modeliai tobulinami integruojant $i ̣$ juos ne tik ekonomikos ir valdymo, bet ir kitų socialinių mokslų modernių koncepcijų elementus.

ISA nauda yra vertinama kaip daugialypé, aktuali visoms suinteresuotųų grupėms:

- padeda mažinti išlaidas, taupiau naudojant išteklius;

- padeda pritraukti ir išlaikyti geriausius darbuotojus;

- padeda gerinti ịmonès ịvaizdį visuomenèje;

- leidžia kurti naujus produktus;

- lengviau atveria naujas rinkas;

- mažina teisinę riziką ir draudimo išlaidas;

- padeda užtikrinti geresnę gyvenimo kokybę.

Juščius (2007) skiria šiuos İSA privalumus:

- užtikrina grižtamajji ryšį tarp įmonés ir aplinkos;

- su suinteresuotomis grupėmis aptariant kylančius prieštaravimus, skatina ieškoti problemų sprendimo būdų;

- ilgam padidina įmonès darnios plètros galimybes.

Kaip teigia Česynienè ir Neverkevič (2009), nagrinėjant mokslinę literatūrą apie İSA, pastebètas diskutuotinas klausimas dèl İSA łgyvendinimo skirtingo dydžio, tipo bei kilmès įmonèse. Dažnai minima, jog İSA iniciatyvių diegimas būdingesnis didelèms įmonems, kurių Lietuvoje nèra labai daug. $\mathrm{O}$ smulkaus ir vidutinio verslo įmonés dažniai sumenkina savo poveikị aplinkai, bendruomenei, kitoms ịmonèms. Tyrimai rodo, kad jos socialinę atsakomybę vis dar sieja su labdara arba laiko viešujų ryšių priemone, bet ne savo verslo strategijos dalimi. Užsienio patirtis rodo, kad İSA iniciatyvų taikymas smulkiose ir vidutinėse įmonèse yra tiek pat svarbus kaip ir didelèse, tik gali skirtis veiksmų mastas.

Organizacijų socialinè atsakomybė yra plataus spektro procesas, apimantis visą produkto, paslaugosgamybos ir kūrimo ciklą bei su tuo susijusius aplinkosaugos, socialinius, finansinius ir etinius aspektus.Socialinę atsakomybę organizacijos realizuoja kryptingu elgesiu keturiose svarbiausiose - rinkos,aplinkosaugos, santykių su darbuotojais ir santykių su visuomene- srityse (Bagdonienè ir Paulavičienè, 2010).

Valstybė teisès aktuose yra numačiusi nemažai priemonių, kurios galètų ir turètų paskatinti i̇mones integruoti socialiai atsakingo verslo principus ị savo veiklą arba bent jau vykdyti atskiras su İSA susijusias priemones. Tai - subsidijos naujų darbo vietų steigimui, mokestinès lengvatos socialinèms įmonėms, galimybẻ vykdant viešuosius pirkimus taikyti ekologinius, socialinius ir kitus kriterijus tiekejjų

parinkimui, žaliụjų pirkimų programa, galimybè darbuotojui ir darbdaviui lanksčiau, nei numatyta ístatymuose, reguliuoti tarpusavio santykius kolektyvinemis sutartimis ir kt. ISA siekiama skatinti ir neteisinėmis bei nefiskalinėmis priemonėmis, tarp jų - socialiai atsakingų imonių apdovanojimais ir nominacijomis, Baltosios Bangos ženklu, parodomųjų projektų inicijavimu ir rẻmimu, gerų praktikų viešinimu (Simanavičienė, Kovaliov ir Šubonytė, 2011). 


\section{Lietuvos ir užsienio alaus ịmonių socialinès atsakomybės kriterijų palyginimas}

Socialiai atsakingos veiklos klausimas alaus sektoriaus įmonėse ne tik Lietuvoje, bet ir visame pasaulyje aktyviai diskutuotinas, ypač kai savo prigimtimi šios įmonès vykdo socialiai neatsakingą veiklą. Ivairių ịstatymų normų apribota alaus gamybos veikla neleidžia įmonėms išnaudoti visų socialiai atsakingos veiklos priemonių ir teikiamos naudos visuomenei ir pačiai įmonei. Tačiau ne viskas priklauso nuo ịstatymų. Kalbant apie atsakingą veiklą, labai svarbus įmonių savanoriškas İSA priemonių taikymas.

Siekiant palyginti Lietuvos ir užsienio i̇monių praktiką ISSA srityje, buvo atlikta populiariausių alaus gamintojų internetiniuose puslapiuose pateiktos informacijos analizè (žr. 2 lentelę).

2 lentelè. Populiariausių užsienio ir Lietuvos alaus įmonių SA kriterijų palyginimas

\begin{tabular}{|l|c|c|c|c|c|c|c|}
\hline \multicolumn{1}{|c|}{$\begin{array}{c}\text { İmonè/ } \\
\text { Kriterijai }\end{array}$} & $\begin{array}{c}\text { Švtu- } \\
\text { rys - } \\
\text { Utenos } \\
\text { alus }\end{array}$ & $\begin{array}{c}\text { Rinkuš- } \\
\text { kiai }\end{array}$ & $\begin{array}{c}\text { Kalna- } \\
\text { pilio - } \\
\text { Tauro } \\
\text { grupé }\end{array}$ & Heineken & Carlsberg & Guinness & Budweiser \\
\hline 1. Aplinkosauga & + & + & - & - & + & - & - \\
\hline $\begin{array}{l}\text { 2. Dalyvavimas } \\
\text { visuomenineje } \\
\text { veikloje }\end{array}$ & + & - & + & - & + & + & + \\
\hline 3. Darbo santykiai & + & - & - & + & + & - & - \\
\hline $\begin{array}{l}\text { 4. Atsakingas } \\
\text { vartojimas }\end{array}$ & + & - & - & + & + & + & + \\
\hline $\begin{array}{l}\text { 5. Atsakingas } \\
\text { investavimas }\end{array}$ & + & - & - & - & + & - & - \\
\hline $\begin{array}{l}\text { 6. Atsakinga } \\
\text { rinkodara }\end{array}$ & + & - & - & + & + & + & + \\
\hline
\end{tabular}

Šaltinis: sudaryta autorès

2 lentelëje pateikti duomenys rodo, kad İSA priemonių taikymas Lietuvos įmonėse, lyginant su kitų šalių alaus sektoriaus ịmonèmis, vis dar mažai paplitęs. Remiantis įmonių internetiniuose puslapiuose pateiktais duomenis, pastebima tendencija, kad dažniausiai taikomos İSA priemonès yra dalyvavimas visuomeninejje veikloje, atsakingo vartojimo skatinimas ir atsakinga rinkodara. Nemaža dalisužsienio įmonių priklauso pramonès finansuojamoms organizacijoms ir globalioms aludarių organizacijoms, skatinančioms atsakingą alkoholio vartojimą. Tuo tarpu didžiosios Lietuvos alaus gamybos įmonès priklauso Lietuvos aludarių gildijai, kuri taip pat skatina atsakingą alkoholio vartojimą. Kaip bendra socialinès atsakomybès priemonè, taikoma visų analizuotų ịmonių, įvardytina prisijungimo prie alaus daryklų tinklalapiųgalimybė: tik nurodžius, kad asmuo yra sulaukęs 18 m., nukreipiama ị i̇monès tinklalapi, priešingu atveju - lankytojui siūloma prie tinklalapio jungtis vèliau. Tas pats principas galioja ir jungiantis prie Lietuvos aludarių gildijos tinklalapio.

Apibendrinant pateiktos analizès duomenis, darytina išvada, kad tiek Lietuvos, tiek užsienio alaus daryklų tinklalapiuose pateikiama savanoriškai taikomos socialinès atsakomybės priemonès, bet daugiausiai orientuojantis ị atsakingo vartojimo skatinimą. 
Tik dvi analizuotos įmonès savo veikloje taiko visus lentelèje pateiktus kriterijus. Tačiau čia svarbu akcentuoti faktą, kad abi įmonès priklauso vienai akcininkų grupei „Carlsberg Group“, todèl ir įmonès kasdieninès veiklos filosofija tokia pati.

Esminis dalykas, kurị išryškino analizè, - pasyvus İSA principų taikymas alaus gamybos įmonių veikloje pastebimas ne tik Lietuvoje, bet ir kitose šalyse. Sunku pasakyti, kas turi ịtakos tokiai tendencijai. Galima tik spèti, jog nemažai prisidejo įstatymai, varžantys alkoholio gamintojų reklamą, bei reikalingos didelès lèšos, norint igyvendinti visus İSA principus. Ir vis dèlto peršasi nuomonė, kad net ir keleto İSA priemonių vykdymas yra vardan reklaminès kampanijos ir konkurencingumo didinimo. Darytina prielaidą, kad veiklą grịsdamos ISA principais alaus gamybos įmonès tam tikra prasme gali apeiti nepalankius įstatymus.

Verta atkreipti dėmesị $\mathfrak{i}$ alkoholio reklamos draudimus ir apribojimus kitose ES šalyse (žr. 3 lentelę). Šiandien alkoholio reklama griežčiausiai reguliuojama Švedijoje - uždrausta visų svaigiụjų gèrimų reklama televizijoje, radijuje, spaudoje, internete ir lauko reklamoje. Daugelio ekspertų teigimu, griežtais alkoholio reklamos draudimais labiausiai suinteresuota šalies valdžia, kadangi tokiu atveju lengva kontroliuoti rinkos veikejjus, siekiant išlaikyti monopolinę alkoholio rinką. Tuo tarpu, Austrijoje, Belgijoje, Čekijoje, Danijoje ir kai kuriose kitose šalyse nèra jokių alkoholio reklamos draudimų. Pasakytina, kad daugiausiai draudžiama stiprių alkoholinių gèrimų reklama. Tačiau nei stiprieji, nei silpnieji gèrimai beveik nedraudžiami internete ir spaudoje.

3 lentelè. Alkoholio reklamos draudimai ir ribojimai ES šalyse

\begin{tabular}{|c|c|c|c|c|c|}
\hline Europos šalys & TV & Radijas & Spauda & $\begin{array}{c}\text { Interne- } \\
\text { tas }\end{array}$ & $\begin{array}{c}\text { Lauko } \\
\text { reklama }\end{array}$ \\
\hline Airija & Gèrimai iki 25\% stiprumo & Gérimai iki 25\% stiprumo & & & \\
\hline \multicolumn{6}{|c|}{ 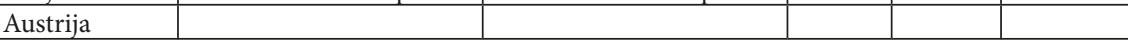 } \\
\hline \multicolumn{6}{|l|}{ Belgija } \\
\hline Bulgarija & $\begin{array}{l}\text { Stiprieji gèrimai tik nuo } \\
22 \text { val. }\end{array}$ & $\begin{array}{l}\text { Stiprieji gèrimai tik nuo } \\
22 \text { val. }\end{array}$ & & & \\
\hline \multicolumn{6}{|l|}{ Čekija } \\
\hline \multicolumn{6}{|l|}{ Danija } \\
\hline Estija & $\begin{array}{l}\text { Silpni nuo } 20 \text { val., stiprieji } \\
\text { nuo } 21 \text { val. }\end{array}$ & $\begin{array}{l}\text { Silpni nuo } 20 \text { val., stiprieji } \\
\text { nuo } 21 \text { val. }\end{array}$ & & & \begin{tabular}{|l|} 
Visiškas \\
draudimas
\end{tabular} \\
\hline \multicolumn{6}{|c|}{ 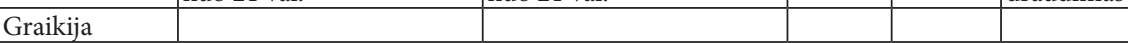 } \\
\hline Ispanija & Gèrimai iki 20\% stiprumo & Gerrimai iki 20\% stiprumo & & & \\
\hline \multicolumn{6}{|c|}{ 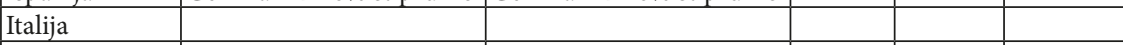 } \\
\hline Latvija & $\begin{array}{l}\text { Tik alus ir silpnieji natūra- } \\
\text { liai fermentuoti }\end{array}$ & $\begin{array}{l}\text { Tik alus ir silpnieji } \\
\text { natūraliai fermentuoti }\end{array}$ & & & Tik alus \\
\hline Lietuva & Nuo 23 val. & Nuo 23 val. & & & Tik alus \\
\hline Lenkija & Tik alus nuo 22 val. & Tik alus nuo 22 val. & Tik alus & & Tik alus \\
\hline \multicolumn{6}{|c|}{ Liuksemburgas } \\
\hline Malta & Nuo 21 val. & Nuo 19 val. & & & \\
\hline \multicolumn{6}{|l|}{ Olandija } \\
\hline Portugalija & Nuo 21.30 val. & Nuo 21.30 val. & & & \\
\hline Prancūzija & Visiškas draudimas & Visiškas draudimas & & & \\
\hline Rumunija & Nuo 22 val. & Nuo 22 val. & & & \\
\hline Slovakija & Tik alus & Tik alus & & & \\
\hline Suomija & Nuo 21 val. & Nuo 21 val. & & & \\
\hline
\end{tabular}




\begin{tabular}{|l|l|l|l|l|l|}
\hline Švedija & Visiškas draudimas & Visiškas draudimas & & & $\begin{array}{l}\text { Visiškas } \\
\text { draudimas }\end{array}$ \\
\hline $\begin{array}{l}\text { Jungtine } \\
\text { Karalyste }\end{array}$ & & & & & \\
\hline Vengrija & Stiprieji nuo 21.30 val. & Stiprieji nuo 21.30 val. & & & \\
\hline Vokietija & & & & & \\
\hline
\end{tabular}

Šaltinis: http://www.ekonomika.lt

Daugelio ekspertų teigimu, reklamos draudimas nestipriai paveikia pardavimus trumpuoju laikotarpiu, tačiau beveik iki minimumo sumažina galimybę išlaikyti esamų prekių ženklus konkurencingus.

\section{Respondentų nuomonès apie alaus gamybos ịmonių socialinę atsakomybę tyrimas}

\section{Tyrimo metodika}

Tyrimas buvo atliktas $2012 \mathrm{~m}$. balandžio mėnesị V. A. Graičiūno aukštojoje vadybos mokykloje bei Vilniaus kolegijoje apklausiant studentus. Tyrimo tikslas buvo ịvertinti, koki poveiki studentams daro alaus gamybos įmonių socialinè atsakomybė ir jos poveikị visuomenei. Tyrime dalyvavo 106 respondentai. Jiems buvo išdalintos anketos, o respondentai jas užpildè. 13 proc. apklaustų respondentų buvo vyrai, o moterys sudarè 87 proc. Iki 20 metų sudare 58 proc. respondentų, 42 proc. respondentų buvo 21-25 metų amžiaus. 89 proc. respondentų mokosi Vilniaus kolegijoje, 11 proc. respondentų mokosi V. A. Graičiūno aukštojoje vadybos mokykloje.

\section{Tyrimo rezultatų analizè}

Respondentams tyrimo metu buvo užduotas klausimas „Ar esate anksčiau girdèjęs (-usi) sąvoką „imonių socialinè atsakomybè (I ISA)?". Tyrimo rezultatai parodè, kad 58 proc. respondentų yra girdèję sąvoką „imonių socialinė atsakomybë“, o 42 proc. respondentų negirdèjo. Vadinasi, respondentus reikètų labiau supažindinti su i̇monių socialinès atsakomybès sąvoka.

Atsakydami ì klausimą „Kaip Jūs apibūdintumète terminą „țmonių socialinè atsakomybe்“ (pabraukite vieną Jums priimtiną variantą)?" 72 proc. respondentų teigè, kad „imonių socialiné atsakomybè - tai immonių ideologija, politika bei praktika, atspindinti tokią ịmonių elgseną, kai jos ị savo veiklą savanoriškai įtraukia socialinius ir aplinkosaugos klausimus bei santykiuose su visais suinteresuotais visuomenès, verslo ir valdžios atstovais vadovaujasi pagarbos žmogui, visuomenei bei gamtai vertybiniais principais“, 13 proc. respondentų teigè, kad „įmonių socialinè atsakomybė - tai terminas, apimantis aplinkosauginių ir socialinių principų savanorišką ịtraukimą i i imonių vidinius procesus ir santykius su visuomene“, 10 proc. respondentų teigè, kad „imonių socialinè atsakomybe் tai terminas, apimantis aplinkosauginių ir socialinių principų savanorišką ịtraukimą $\mathfrak{i}$ immonių vidinius procesus ir santykius su visuomene“, ir 5 proc. respondentų teigè, kad „ịmonių socialinė atsakomybe் - veikti savarankiškai ir organizuoti veiklą taip, kad būtų pasiektas maksimalus pelnas, tačiau kartu tenkinant aplinkinių poreikius“. 
1 pav. Respondentų atsakymai ị klausimą „Iš kur išgirdote apie İSA?", proc.

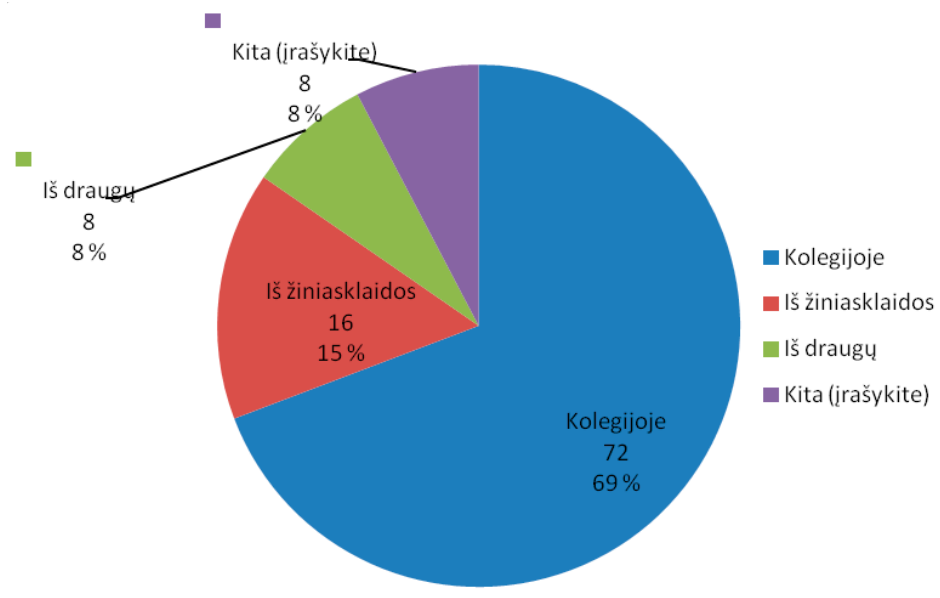

Šaltinis: sudaryta autorès

Kaip matyti iš 1 paveikslo, 72 proc. respondentų apie įmonių socialinę atsakomybę sužinojo kolegijoje, 16 proc. - iš žiniasklaidos ir po 8 proc. respondentų sužinojo iš draugų bei kitų šaltinių. Todèl galima teigti, kad apie İSA respondentai daugiausia išgirdo kolegijoje.

Respondentams buvo užduotas klausimas „Kokie elementai apima įmonių socialinę atsakomybę?". Kaip matyti iš 2 paveikslo, įmonių socialinę atsakomybę sudaro ịstatymų laikymasis, verslo etika, aplinkos apsauga.

2 pav. Respondentų atsakymai ị klausimą „Kokie elementai apima įmonių socialinę atsakomybę?", proc.

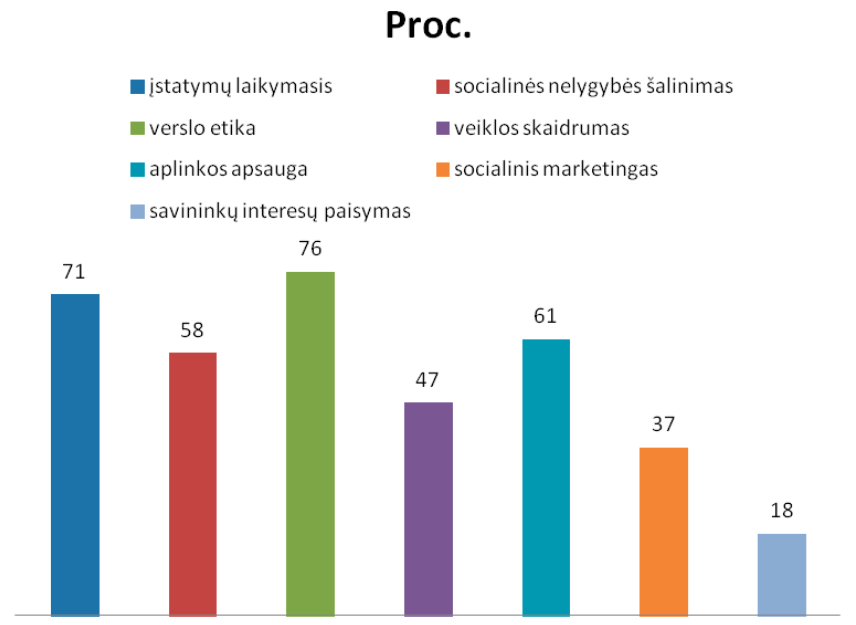

Šaltinis: sudaryta autorès 
Atsakydami ị klausimą „Ar esate girdèjęs(-usi) apie alaus gamybos įmonès veiklą visuomenès labui?"“ 18 proc. respondentų teigè, kad yra girdejję, o 82 proc. teigè, kad negirdèjo apie tai. Todèl galima teigti, kad reikètų respondentus labiau informuoti apie alaus gamybos įmonių veiklą visuomenès labui.

I klausimą „Ar esate girdèjęs (-usi) apie alaus gamybos įmonių vykdomas socialinès atsakomybès programas?" 92 proc. respondentų atsakè, kad nèra girdèję apie socialinès atsakomybès programas, o 8 proc. respondentų teigé, kad yra girdèję. Vadinasi, arba tų programų nèra daug, arba respondentai apie jas neinformuojami.

Atsakydami ị klausimą „Kaip manote, ar savo prigimtimi vykdančioms neatsakingą veiklą i̇monėms (pvz., alaus gamybos) tikslinga plètoti įmonès socialinę atsakomybę?" 66 proc. respondentų teigè, kad tai daryti būtų tikslinga, o 34 proc. respondentų teigè, kad netikslinga. Galima daryti išvadą, kad vis dèlto tikslinga būtų plètoti ịmonès socialinę atsakomybę.

Atsakydami ị klausimą „Kaip Jūs vertinate alaus gamybos įmonių vykdomas socialinès atsakomybés priemones?" labai teigiamai respondentai vertino daugiausia tokias priemones kaip aplinkos apsauga (21 proc. respondentų), dalyvavimas visuomeninèje veikloje (26 proc. respondentų), įvairiapusis rèmimas (sporto varžybų, kultūros renginių ir pan.) (47 proc. respondentų). Labai neigiamai buvo įvertintos tokios priemonès kaip aplinkos apsauga (3 proc. respondentų), atsakingo vartojimo skatinimas (3 proc. respondentų) (žr. 4 lentelę).

4 lentelè. Respondentų atsakymai ị klausimą „Kaip Jūs vertinate alaus gamybos įmonių vykdomas socialinès atsakomybès priemones?", proc.

\begin{tabular}{|c|c|c|c|c|c|}
\hline${ }^{-}$Vertinimas & $\begin{array}{c}\text { Labai } \\
\text { teigiamai }\end{array}$ & Teigiamai & $\begin{array}{c}\text { Nei teigiamai, nei } \\
\text { neigiamai }\end{array}$ & Neigiamai & $\begin{array}{c}\text { Labai } \\
\text { neigiamai }\end{array}$ \\
\hline Priemonè & & . & Proc. & & \\
\hline Aplinkos apsauga & 21 & 21 & 47 & 8 & 3 \\
\hline $\begin{array}{l}\text { Atsakingo vartojimo } \\
\text { skatinimas }\end{array}$ & 13 & 34 & 34 & 24 & 3 \\
\hline Atsakinga rinkodara & 8 & 24 & 61 & 8 & - \\
\hline $\begin{array}{l}\text { Darbo santykiai (skatinimas, } \\
\text { motyvavimas ir pan.) }\end{array}$ & 18 & 37 & 34 & 11 & - \\
\hline $\begin{array}{l}\text { Dalyvavimas visuomeninèje } \\
\text { veikloje }\end{array}$ & 26 & 32 & 32 & 10 & - \\
\hline $\begin{array}{l}\text { Ivairiapusis rèmimas } \\
\text { (sporto varžybų, kultūros } \\
\text { renginių ir pan.) }\end{array}$ & 47 & 24 & 29 & - & - \\
\hline
\end{tabular}

Šaltinis: sudaryta autorès

12 anketos klausimu buvo siekiama išsiaiškinti, „Dèl kokių priežasčių, Jūsų nuomone, yra vykdoma i̇monių socialinė atsakomybė?" Tyrimo rezultatai parodè, kad pagrindinès priežastys yra šios: geresnè įmonès reputacija ( 87 proc. respondentų), gaunama „nemokama reklama“ (66 proc. respondentų), klientų lojalumo didinimas (42 proc. respondentų) bei finansinè nauda įmonei (42 proc. respondentų) (žr. 3 paveikslą). 
3 pav. Respondentų atsakymai ị klausimą „Dèl kokių priežasčių, Jūsų nuomone, yra vykdoma įmonių socialinè atsakomybè?", proc.

\section{Proc.}

\begin{tabular}{|c|c|}
\hline Darbuotojų lojalumas & Geresnè įmonès reputacija \\
\hline Konkurencingumo didejjimas & Elientų lojalumo didèjimas \\
\hline
\end{tabular}

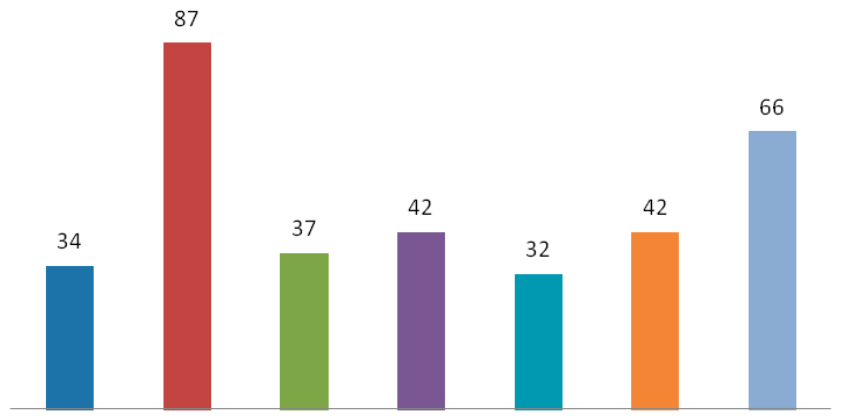

Šaltinis: sudaryta autorès

I klausimą „Ar alaus sektoriaus įmonès I̦SA igyvendina tik dèl reklaminès

kampanijos?" 58 proc. respondentų atsake teigiamai ir 42 proc. teigé, kad ne vien tik dèl reklaminès kampanijos.

14 anketos klausimas buvo toks: „Kaip manote, ar visuomenė gali įtakoti įmonių socialinę atsakomybę?“. 18 proc. teigè, kad labai stipriai, 50 proc. - stipriai ir 32 proc. - nei stipriai, nei nestipriai. Todèl galima daryti išvadą, kad visuomenė gali turèti pakankamai įtakos įmonių socialinei atsakomybei.

15 anketos klausimu buvo siekiama išsiaiškinti „Kaip valstybės institucijų veikla gali paveikti i̇monių socialinę atsakomybę?"“ 32 proc. respondentų atsakè, kad labai stipriai, 46 proc. - stipriai, 18 proc. - nei stipriai, nei nestipriai ir 2 proc. - nestipriai. Galima daryti išvadą, kad valstybès institucijų veikla gali pakankamai stipriai paveikti immonių socialinę atsakomybę.

Uždavus klausimą „Ar jaučiate pareigą skatinti įmonių socialiai atsakingą veiklą?" 63 proc. respondentų teigè, kad jaučia pareigą, o 37 proc. respondentų teigè, kad pareigosnejaučia. Vadinasi, reikia keisti respondentų pasaulěžiūrą, kad jie dar daugiau skatintų įmonių socialinę atsakomybę.

Atsakymai ị klausimą „Ar Jūsų pasirinkimui pirkti alų turi ịtakos įmonès rūpinimasis aplinka ir visuomene?" pasiskirstė taip: 26 proc. respondentų teigè, kad turi, 74 proc. respondentų teigé, kad neturi.

Paskutiniu anketos klausimu buvo siekiama išsiaiškinti „Kas, Jūsų nuomone, skatina socialiai atsakingos veiklos igyvendinimą?“. Kaip matyti iš 5 lentelès, labiausiai skatina geresnè i̇monès reputacija (37 proc. respondentų), klientų lojalumo didejimas (18 proc. respondentų) bei konkurencingumo didinimas bei vietos bendruomenès palaikymas (16 proc. respondentų). 
5 lentelè. Respondentų atsakymų ị klausimą „Kas, Jūsų nuomone, skatina socialiai atsakingos veiklos igyvendinimą?" pasiskirstymas

\begin{tabular}{|l|c|c|c|c|c|}
\hline \multicolumn{1}{|c|}{ Veiksniai } & $\mathbf{1}$ & $\mathbf{2}$ & $\mathbf{3}$ & $\mathbf{4}$ & $\mathbf{5}$ \\
\cline { 2 - 6 } & & & Proc. & & \\
\hline Darbuotojų lojalumas & 8 & 18 & 37 & 26 & 13 \\
\hline Geresnė įmonių reputacija & 2 & 8 & 32 & 21 & 37 \\
\hline Konkurencingumo didèjimas & 11 & 5 & 26 & 42 & 16 \\
\hline Klientu lojalumo didejjimas & 8 & - & 42 & 32 & 18 \\
\hline Vietos bendruomenės palaikymas & 5 & 16 & 32 & 32 & 16 \\
\hline Finansinè nauda i̇monemms & 5 & 10 & 34 & 18 & 32 \\
\hline Gaunama nemokama reklama & 5 & 5 & 18 & 29 & 57 \\
\hline
\end{tabular}

Šaltinis: sudaryta autorès

\section{Išvados}

Imonių socialinè atsakomybè - tai įmonių ideologija, politika bei praktika, atspindinti tokią ịmonių elgseną, kai jos ị savo veiklą savanoriškai ịtraukia socialinius ir aplinkosaugos klausimus bei santykiuose su visais suinteresuotais visuomenès, verslo ir valdžios atstovais vadovaujasi pagarbos žmogui, visuomenei bei gamtai vertybiniais principais.

Lyginant Lietuvą su kitomis ES valstybėmis narėmis matomas žymus atotrūkis. Daugelio iš rekomenduojamų ISA priemonių Lietuvos įmonės netaiko, ypač tai svarbu kalbant apie veiklos skaidrumo užtikrinimą ir socialiai atsakingos veiklos politikos vystymą.

Lietuvoje socialinès atsakomybès sąvoka įmonių pradèta vartoti visai neseniai. ISA nauda yra ịvairiapusè: padeda gerinti įmonės ịvaizdi, pritraukti ir išlaikyti geriausius darbuotojus, sumažinti energijos ir atliekų kiekį bei joms skiriamas išlaidas, prisideda prie geresnio gyvenimo kokybès gerinimo ir kt.

İmonių socialinė atsakomybè yra organizacinès kultūros dalis, kaip ir organizacinès kultūros aplinkosvertybės. Apibendrinus galima teigti, kad organizacinè kultūra bei ịmonių socialinè atsakomybė yra tarpusavyje susijusios sąvokos, nes jomis yra parodoma organizacijoje vyraujanti etinè, kultūrinè bei moralinè aplinka (Šimanskienė ir Pažuolienė, 2010).

Dažniausiai taikomos İSA priemonès alaus gamybos įmonėse yra dalyvavimas visuomenineje veikloje, atsakingo vartojimo skatinimas ir atsakinga rinkodara. Nemaža dalis užsienio i̇monių priklauso pramonès finansuojamoms organizacijoms ir globalioms aludarių organizacijoms, skatinančioms atsakingą alkoholio vartojimą.

Tyrimo rezultatai parodè, kad:

* Jaunimą reikètų labiau supažindinti su įmonių socialinès atsakomybės sąvoka.

* Respondentaiįmonių socialinę atsakomybę suvokia kaip įstatymų laikymąsi, verslo etiką, aplinkos apsaugą.

* Reikètų visuomenę labiau informuoti apie alaus gamybos įmonių veiklą visuomenès labui.

* Pasak respondentų, savo prigimtimi vykdančioms neatsakingą veiklą i̇monèms vis dèlto tikslinga būtų plètoti įmonès socialinę atsakomybę.

* Dauguma respondentų teigè, kad jie nèra girdèję apie socialinès atsakomybès programas, todèl būtina ateityje juos apie tai informuoti.

* Labai teigiamai respondentai vertino daugiausia tokias priemones kaip aplinkos apsauga, dalyvavimas visuomeninejje veikloje, ¿̨vairiapusis rẻmimas (sporto varžybų, kultūros renginių ir pan.). 
* Pagrindinès priežastys, skatinančios įmonès socialinę atsakomybę, yra geresnè įmonės reputacija, gaunama nemokama reklama, klientų lojalumo didinimas bei finansinè nauda įmonei.

* Respondentų nuomone, socialiai atsakingos veiklos igyvendinimą labiausiai skatina geresnè įmonès reputacija, klientų lojalumo didejjimas, konkurencingumo didinimas bei vietos bendruomenès palaikymas.

Siūlomos šios rekomendacijos įmonèms, susidomejjusiomis İSA teikiama nauda:

- SA padeda išlaikyti geriausius darbuotojus, kyla jų motyvacija dirbti bei būti lojaliems organizacijai, šiose organizacijosedarbuotojai jaučiasi saugiau;

- padideja ekonominis efektas, nes organizacijoms, įdiegusioms İSA standartą ir principus, atsiranda didesnès perspektyvos sulaukti finansinių pasiūlymų iš ekonomiškai stiprių organizacijų, kurios ir pačios vertina kitas organizacijas, besilaikančias šių principų;

- atsiranda galimybė geriau patenkinti savo vartotojų (klientų, pacientų, t. t.), o kartu ir visuomenés poreikius, nes laikomasi aplinkosaugos reikalavimų;

- suformuojamas geras įmonès vardas, savo firminio ženklo - patikimos įmonės- reputacija, kuri palanki tiek darbuotojams, tiek visuomenei.

\section{Literatūra}

Bagdonienè, D., ir Paulavičienè, E. (2010). Socialinès atsakomybès ir organizacijos vadybos sistemos integravimas. Ekonomika ir vadyba.15: 366-373.

Bernatonyte, D., Vilkè, R., ir Keizerienė, E. (2009). Ekonominès krizès poveikio Lietuvos smulkių ir vidutiniu įmonių socialinei atsakomybei kryptys.Ekonomika ir vadyba.14: 229-236.

Carrasco, I. (2008). Moral Traits of Adam Smith's theories in corporate social responsibility evolution. University of Castilla -La Mancha. JEL: A13, B12. Prieiga per internetą: http://www.giuri.unipd. it/ AISPE-2008/S007D9876.12/Carrasco.pdf. [žiūrèta 2012-04-21].

Česynienè, R., ir Neverkevič, M. (2009). Imonių socialinė atsakomybè ir jos iniciatyvų diegimo kliūtys smulkiojo ir vidutinio verslo įmonèse. Verslas, vadyba ir studijos. Vilnius: VGTU, p. 261-270.

Čiegis, R. (2003). Darnus vystymasis: ekonominiai aspektai. Kaunas: Aplinkosaugos valdymo ir technologijų centras, p. 21-45.

Čiegis, R., ir Gineitienè, D. (2008). Participatory aspects of strategic sustainable development planning in local communities: Experience of Lithuania.Technological and Economic Development of Economy.14(2): 107-117.

Dagilienė, L., ir Bruneskienė, J. (2010). Savanoriškai atskleidžiamos informacijos vaidmuo įmonių socialinès atsakomybės aspektu. Ekonomika ir vadyba. 14: 451-456.

Darbo ir socialinių tyrimų institutas, Socialinès apsaugos ir darbo ministerija, Lietuvos Respublikos trišalè taryba (2006). Aktualūs socialinès politikos klausimai. İmonių socialinè atsakomybè.

Komisijos komunikatas Europos Parlamentui, Tarybai bei Europos ekonomikos ir socialinių reikalų komitetui (2006). Augimo ir užimtumo partnerystés igyvendinimas paversti Europa įmoniu socialines atsakomybès pavyzdžiu. Briuselis. Prieiga per internetą: http://eur-lex.europa.eu/ LexUriServ/LexUriServ.do?uri=COM:2006:0136:FIN:LT:HTML. [žiūrèta 2012-04-21].

Lapinskiené, G., ir Tvaronavičienè, M. (2009). Darnusis vystymasis Centrineje ir Rytų Europoje: pagrindiniai ekonominio augimo aspektai.Verslas: teorija ir praktika. 10(3): 204-213.

Lietuvos Respublikosalkoholio kontrolès ịstatymo pakeitimo ịstatymas. Valstybès žinios. 2004, Nr. 47-1548.

Lietuvos Respublikossocialinès apsaugos ir darbo ministerija (2012). İmonių socialinè atsakomybė Lietuvoje: praktiniai atsakingo verslo pavyzdžiai. Prieiga per internetą: http://www.socmin.lt/ index.php?-211085659. [žiūrèta 2012-04-21]. 
Lietuvos Respublikos Vyriausybès 2010 m. sausio 12 d. nutarimas Nr. 53 „Dèl nacionalinės ịmonių socialinès atsakomybès plètros 2009-2013 metų programos ir jos igyvendinimo 2009-2011 metų priemonių plano patvirtinimo“. Valstybés žinios. 2008, Nr. 124-4718.

Marrewijk, M. (2003). Concepts of Definitions of CSR and Corporation Sustainability: Between Agency and Communion. Journal of Business Ethics. 44, 2/3. Prieiga per internetą: http://www.springerlink.com/content/t7175m6131691452/fulltext.pdf. [žiūrèta 2012-04-21].

Mares, R. (2007). The Dynamics of Corporate Social Responsibilities. Netherlans. Prieiga per internetą:http://books.google.com/books. [žiūretta2011-04-21].

Juščius, V. (2007).Verslo socialinès atsakomybės teorijų raida. Ekonomika. 78: 48-59.

Juščius, V. (2009). Imonių socialinè atsakomybė ir organizacijų tapatumas šiuolaikinès ekonominės krizès kontekste. Ekonomika ir vadyba.14: 264-271.

Pruskus, V.(2003). Verslo etika: laiko iššūkiai ir atsako galimybės. Vilnius: Enciklopedija.

Ruževičius, J., ir Serafinas, D. (2006). Socialiai atsakingo verslo plètra Lietuvoje.Inžinerinè ekonomika Engineering Economics. (2): 36-44.

Schieg, M. (2009). İmonių socialinès atsakomybės vadybos modelis. Verslas: teorija ir praktika.10(4): 315-321.

Simanavičienė, Ž., Kovaliov, R., ir Šubonyte, J. (2011). İmonių socialinès atsakomybès skatinimo politikos Lietuvoje SSGG analizè. Ekonomika ir vadyba.16: 605-611.

Šimanskienė, L., ir Pažuolienė, J. (2010). Imonès socialinès atsakomybès svarba Lietuvos organizacijoms. Management theory and studies for rural business and infrastructure development. 20 (1): 138-145.

Šimanskienė, L., ir Pažuolienė, J. (2010). İmonių socialinès atsakomybès ir organizacinès kultūros sąsajų tyrimas Lietuvos organizacijose. Management theory and studies for rural business and infrastructure development. 23(4):1-11.

Tafel-Viia, K., ir Alas, R. (2009). Valdytojų ir vyresniųjų vadybininkų skirtumai ir konfliktai esant socialinei atsakomybei kontekste.Inžinerine ekonomika - Engineering Economics. (4): 86-95.

UAB „EKT Grupe““. Tyrimo ataskaita. (2007). Socialines atsakomybes tendencijos tarp smulkiu ir vidutiniu įmonių. Prieiga per internetą: http://www.atsakingasverslas.lt/docs/CSR_ataskaita_galutine.pdf. [žiūrèta 2012-04-21].

UAB Intelektualių resursų sistemos(2012). SA 8000. Socialinès atsakomybès standartas. Prieiga per internetą: http://www.irs.lt/lt/socialine/atsakomybe/SA/8000. [žiūrèta 2012-04-216].

Vaitkevičius, S., ir Stukaité, D. (2009). İmonių socialinès atsakomybès formavimas racionalaus veikimo kontekste. Ekonomika ir vadyba. 14: 624-632.

Vasiljevas, A., ir Pučètaitè, R. (2005). Socialinės įmonių atsakomybės ir efektyvaus žmogiškujjų išteklių valdymo igyvendinimas dalykinès etikos priemonèmis. Organizaciju vadyba: sisteminiai tyrimai. 36: 193-208. 


\title{
BEER PRODUCTION ENTEPRISES CORPORATE SOCIAL RESPONSIBILITY RESEARCH IN COLLEGES
}

\author{
Margarita IŠORAITÉ \\ V. A. Graičiūnas High Management School, Lithuania
}

\begin{abstract}
The article analyzes the concept of corporate social responsibility, more importantly, corporate social responsibility in Lithuanian politics. Many references are given according to the main reasons why CSR issues are of strategic importance: it is a natural stage of development organizations in the light of changing public expectations; exhaustion of natural resources have become the limiting factor in the development activities; environmental problems have become global in scale; there is a growing health problem; the social, environmental and economic factors associated with each other create instability and insecurity; security of energy supply is becoming a critical issue; sustainable development principles may lead to more positive outcomes than planned in advance. Empirical research has shown that the public should be more familiar with the concept of corporate social responsibility. The public is more aware of the brewing companies in the public interest. By its nature, engaged in irresponsible companies, it is, therefore, appropriate to develop corporate social responsibility. Most respondents said they have not heard about the social responsibility programs. Thus, it is necessary to inform them about this phenomenon in the future. Respondents positively evaluated measures, such as environmental protection, participation in social activities and diverse support (sports, cultural events, etc.). According to the respondents, the public and the authorities are able to influence corporate social responsibility. The main reasons for promoting corporate social responsibility are a better company's reputation resulting from the "free advertising", customer loyalty and increase of the financial benefits of the company.
\end{abstract}

Keywords: corporate social responsibility, social responsibility policy, the social responsibility of the entrepreneur 